\title{
Collaborative tourism planning and subjective well-being in a small island destination
}

\begin{abstract}
This research employed a case study method to examine how a tourism planning process was utilized to discuss resident and community subjective well-being. Sitka, Alaska, a small island community, embarked on a collaborative tourism planning effort as an activity to guide and manage tourism development, particularly development from nonlocal interests that was perceived by some as threatening well-being and quality of life. A general interview guide approach and 27 interviews with key informants were conducted, as well as the plan document was consulted as a proxy for additional insight into processes, structure, and their interaction. The research inquiry focused on how subjective well-being was defined; how length of residency, livelihood, and role in the community influenced well-being; and how tourism development and concerns over well-being fueled tourism planning. The paper concludes with theoretical and destination management and marketing implications.
\end{abstract}

Keywords: resident attitudes, community, case study, qualitative methods

(C) 2015. This manuscript version is made available under the Elsevier user license http://www.elsevier.com/open-access/userlicense/1.0/ 


\section{Collaborative tourism planning and subjective well-being in a small island destination}

\section{Introduction}

Small island tourism destinations are uniquely positioned to be both sensitive to and proactive about tourism development in their communities (Carlsen \& Butler, 2011; Jordan, Vogt, Kruger, \& Grewe, 2013). As distinct locales with well-defined geographic boundaries, separation from mainstream/mainland, and small populations, small island destinations create and sustain tight-knit protective communities with distinct cultural identities (Cross \& Nutley, 1999). The isolated nature of island destinations makes it difficult for residents to ignore or avoid potential tourism development impacts (Hamzah \& Hampton, 2013; Nunkoo \& Ramkissoon, 2010). Decisions regarding small island destination tourism development and resulting impacts have the potential to affect the subjective well-being of residents living in island tourism destinations (Douglas, 2006).

Subjective well-being is the sum of an individual's perception of their life and their “living" environment comprised of social, economic, and environmental factors (Diener, 2000). Psychologists further describe subjective well-being as an individual's cognitive evaluation of their own life as positive, and can include pleasure, the absence of negative emotions, and high satisfaction with life (Diener, Lucas, \& Oishi, 2009). Subjective well-being is not a static state, as individuals and groups continually evaluate their interaction with their environment (Luhmann, Hofmann, Eid, \& Lucas, 2012). Subjective well-being is central to residents’ perception and evaluation of their local quality of life and other environmental factors such as their living environment or shared space with tourists. The perception of subjective well-being by tourism destination residents implies that as individuals, and as part of the greater community, 
they enjoy their life with tourism activities and do not perceive tourism development as a threat to the environment, quality of life, community well-being, or economic opportunity. One approach individuals take to manage external influences on subjective well-being is through participation in community activities designed to shape the social and physical community (Dolan, Peasgood, \& White, 2008). Within the context of small island tourism destinations, residents may choose to address tourism development proactively through tourism planning designed to manage growth and maintain subjective well-being (Jordan, 2015).

Collaborative tourism planning has received significant attention as a way to proactively manage growth and development in a variety of destinations (Byrd, 2007). The collaborative tourism planning process allows for the many stakeholders in tourism destinations to consider tourism development and how their well-being will be affected by no, slow, or rapid growth (Jamal \& Getz, 1995). Collaborative tourism planning is different than other types of planning in that it allows for the participation of greater numbers of stakeholders, likely resulting in great variations in perception of well-being. Through collaborative planning, perceptions of well-being serve to guide the vision, mission, goals, and objectives of the plan to manage tourism development using a broader community framework (Jamal \& Stronza, 2009).

Despite significant potential for impacts in small island tourism destinations, little is known about how tourism development and collaborative tourism planning affect residents' perceptions of well-being. This study aims to fill this knowledge gap by examining the relationship between collaborative tourism planning and the perception of subjective well-being using a case study of a community that used collaborative tourism planning to guide tourism development. This study posits that collaborative tourism planning in Sitka, Alaska a small island tourism destination, provided opportunity for residents to consider their own definitions of well-being and manage tourism to promote well-being at the community level. This case-study 
examines the individual characteristics that influence the meaning and perception of subjective well-being and highlights the relationships between tourism development and subjective wellbeing through the collaborative tourism planning process. The applied purpose of this research is to enrich tourism practitioner understanding of the influences on collaborative tourism planning processes and their outcomes.

\section{Literature Review}

This literature review focuses on subjective well-being as a cognitive state held by residents of tourism destinations, tourism development in small island destinations, and collaborative tourism planning.

\section{Subjective Well-Being}

Subjective well-being is defined as an individual's feelings and thoughts about life circumstances as they proceed through their life (Diener, Suh, Lucas, \& Smith, 1999). Similar concepts include satisfaction with life, quality of life, and happiness (Costanza et al., 2007). While the general term of well-being is inclusive of love, pleasure, or quality of life, subjective well-being enables individuals to create and maintain their own definition and perception of what constitutes a good life (Schalock, 1997). The processes that link being happy with well-being are thought to play an important role in perception of well-being (Diener, 2000; Diener et al., 1999). As such, a myriad of individual characteristics like personality, socioeconomic status, and geographic location play a role in how individuals perceive well-being (DeNeve \& Cooper, 1998; Kahneman \& Krueger, 2006).

The experience of subjective well-being has been negatively linked with poor health outcomes, meaning those who perceive high levels of well-being generally experience fewer depressive symptoms, anxiety, and physical health issues (Diener \& Chan, 2011). An individual's level of participation and perception of influence in local development, including 
tourism planning and development, is also related to their perception of tourism and their sense of well-being (Yuksel, Bramwell, \& Yuksel, 1999). Madrigal (1995) specifically posited increased participation in local planning activities and greater perceived influence on community tourism decisions reinforced the belief that tourism communities provide high quality of life.

\section{Small Island Tourism Development}

Tourism development includes any actions by public or private organizations aimed at facilitating the visitation of tourists. Pearce (1989) defined tourism development as "the sum of dynamic processes, activities, and outcomes originating from the relationship between the actors... involved in the tourism phenomenon, with the ultimate goal of endowing the residents of a destination with the freedom to decide on their own development." Tourism development has long been viewed as a driver of economic growth for small island destinations with resources that are viewed as attractive to potential tourists (Scheyvens \& Momsen, 2008b; Shareef \& McAleer, 2005). Tourism development is often touted as an economic panacea for many tourism destinations, and small island destinations are no different. In contrast to many contexts, this relationship has been found to hold true to some extent in small island destinations, with tourism development enjoying a bi-causal relationship with overall economic growth (Seetanah, 2011). Tourism development also has the potential to affect sense of community in small island tourism destinations through changes to social systems and natural resources (Lim \& Cooper, 2009). Social systems might be the ability to navigate downtown areas during peak tourism times also known as traffic congestion or garbage collection and disposal from residents' and tourists' waste (Green, 2005). Nature resources are impacted in many ways including the construction of infrastructure and superstructure. These types of impacts are often particularly visible to residents of small islands because of their small geographical footprint (Hamzah \& Hampton, 2013). 
When faced with the prospect of tourism development, small island destinations with control over tourism decision making are challenged to determine levels of change that are acceptable to the greater community (Scheyvens \& Momsen, 2008a). For instance, some communities may be open to the redevelopment of a downtown area, while others may wish to maintain the existing downtown character. Sense of community is one element in the decisionmaking process that often plays an important role in individuals' subjective well-being (Andereck, Valentine, Knopf, \& Vogt, 2005). While there are many structures within which tourism planning can be undertaken, one type of tourism planning that allows for a great deal of community input and discourse about community well-being is collaborative tourism planning (Jamal \& Getz, 1995; Jordan et al., 2013).

\section{Collaborative Tourism Planning}

In general, planning is an essential activity for communities seeking to integrate tourism into their economic, environment, and social endeavors (Gunn, 1988). Tourism development has often been viewed as an imposed action, done with little input from the majority of community residents or non-tourism sectors (Moscardo, 2011). Tourism development, however, needs to adhere to local land use plans and zoning ordinances, may need environmental impact assessments required by government agencies, and should adhere to local development plans and economic development strategies (Go, Milne, \& Whittles, 1992). Resident input on tourism planning matters should be collected and applied with great care. Citizen input may be from a layperson's point of view and may lack some of the background and technical knowledge needed later in decision-making. Any planning process, including collaborative, uses human judgment to select the best time to solicit resident input and then apply that input into a planning document and ultimately practice (Ritchie, 1993). 
Collaborative theory indicates that "collaboration occurs when a group of autonomous stakeholders of a problem domain engage in an interactive process, using shared rules, norms, and structures, to act or decide on issues related to that domain" (Wood \& Gray, 1991, p. 146). Jamal and Getz's (1995) Proposition 4 states that "collaboration for tourism destination planning will depend on encompassing the following key stakeholder groups: local government plus other public organizations having a direct bearing on resource allocation; tourism industry associations and sectors such as chamber of commerce, convention and visitors bureau, and regional tourist authority; resident organizations, social agencies, and special interest groups.” (p. 198). The first stage of the collaborative tourism planning process involves 'problem setting,' in which stakeholders are identified and asked to determine which issues the collaborative tourism plan is to address (Jamal \& Getz, 1995).

After problem setting and initial group forming, collaborative or participatory planning allows local stakeholders to consider social, cultural, economic, and environmental impacts; voice their opinions; and arrive at plans where sustainability or triple-bottom line social, economic, and environmental outcomes are achieved (Bramwell \& Sharman, 1999; Nunkoo \& Ramkissoon, 2011; Zapata \& Hall, 2012). Additionally, recent research on planning models indicates collaboratively created tourism plans are more successfully implemented and sustained than other types of tourism planning (such as expert led tourism planning) due to resident buy-in during early stages of the planning process (Okazaki, 2008; Plummer, Kulczycki, \& Stacey, 2006). A sense of ownership, buy-in, and control is established in collaborative planning techniques that can sustain implementation over the long-term. Despite the positive attributes of collaborative planning approaches, swing votes, interest groups that are involved or absent from the process, and outside developers can change community consensus or stall implementation. 


\section{Case Study Context}

An in-depth case study of Sitka, Alaska was conducted to explore the relationship between collaborative tourism planning and subjective well-being. Sitka was selected over other small island or coastal communities in the Pacific Northwest region because of recent planning activities that incorporated collaborative planning into their approach for discussing and planning for community long-term needs and opportunities, which includes tourism. Sitka is a small town of approximately 8,600 residents located on Baranof Island in Southeast Alaska's famed Alexander Archipelago. The downtown is surrounded by the Tongass National Forest - the world's largest temperate rainforest. Sitka's history is a unique blend of native Tlingit culture, early Russian settlement, and American pioneer town as Alaska’s first capital city (1867-1906). For many years, Sitka's economy was based on a timber pulp mill, commercial fishing, and tourism. At its peak, the mill directly employed 400 workers, supported an additional 400 to 600 indirect timber jobs, and provided $10 \%$ of the community's wage jobs and $18 \%$ of the local payroll (Gilbertson, 2003). When the pulp mill closed in 1993 the community worked to expand its tourism base by attracting more in-state and regional visitors. Today, Sitka's tourism infrastructure includes 200 hotel rooms, several dozen bed and breakfast operations or lodges, and public and private campgrounds. Of noteworthy importance, 24 Sitka attractions are listed on the National Register of Historical Places. Commercial and recreational fishing is important to Sitka's economy as evidenced by a history of being among the top 25 ports for fish landings in the United States (Gilbertson, 2003).

Cruise ships visit Southeast Alaska during peak tourist season (May - September). Large scale and modern-style cruising in Southeast Alaska started during the 1970s and boomed across the region during the 1990s. Cruise visitation reached current day passenger volumes during the late 1990s and steadily grew until the onset of the national recession during 2008. Cruise 
visitation declined in the years immediately following the recession, but has since stabilized. Following region-wide trends, Sitka's cruise visitation reached a high of 290,000 visitors in 2008 followed by an all-time low of 110,714 visitors in 2012 (Cruise Line Agencies of Alaska, 2012). Sitka's total cruise visitation volume has not returned to pre-recession levels. In addition to the national recession, many attribute the volatility of Sitka's cruise visitor volume to the lack of a dock to facilitate the direct unloading and loading of passengers and its location along Alaska's outer coast, which has experienced a significant decrease in the frequency of Gulf of Alaska crossings by multiple major cruise lines.

There are two local governments in Sitka - the locally-elected municipal government, comprised of a mayor and assembly, and a tribal government. Two tourism entities are also associated with the local government - the Convention and Visitors Bureau (CVB) and the Tourism Commission. The CVB is a member-based organization that markets Sitka and provides visitor services to inbound tourists. The Tourism Commission includes seven appointed members with designated representation from the tribe, chamber, conservation community, commercial enterprises, CVB, and at-large membership. The Commission plays a planning role by advising and making recommendations to the assembly on tourism-related community issues and by engaging other organizations including local, tribal, state, and federal government offices, businesses, nonprofits, and the community at large.

To address changes in cruise visitation and local concerns regarding the overall direction of tourism development in the community, the locally-elected Sitka assembly commissioned a collaborative tourism planning process.

\section{Methods}

A case study approach was used to examine tourism planning at a local level and analyze its relationship with subjective well-being (Stake, 1978; Xiao \& Smith, 2006; Yin, 2012). Case 
studies are especially useful when using multiple sources of evidence to explore the contextual aspects of complex issues in contemporary real-life situations (Yin, 2012). Case studies conducted in small communities are most common in tourism research (Xiao \& Smith, 2006). Utilizing a case study approach of one community that is a popular tourist destination - Sitka, Alaska - allowed for an in-depth analysis of a collaborative tourism planning process. Included in the case study method were semi-structured, in-depth interviews (Crotty, 1998; Patton, 2002). In-depth interviewing involves asking questions that provide open-ended qualitative data. Data are generated as the interviewer listens and records the interviewee's answers. In the semi-structured interviews, a guide of questions written by the researchers was used, but not every interview strictly followed the order of the questions as found in a fully standardized interview. Interviews allowed the researchers to learn how individuals were involved (or not) in planning and how they viewed the planning process. Subjective well-being was not a specific question in the interview guide, but instead emerged during conversations. Thus, interviews enabled deeper interpretation of community engagement in tourism planning than other types of data collection.

Interview questions were developed before entering the field using Corbin and Strauss's (2015) theoretical interest approach. The theoretical interest of the research was to examine collaborative tourism planning and the role it played in community and individual quality of life and sustainability. A series of questions were developed for the interview script around the themes of demographics, quality of life, community and economic planning and development, tourism planning and activities, and sustainability. Each theme had multiple questions and several written probes, used to elicit deeper responses. An example of quality of life questions included: what do you like best about Sitka? What are points of pride? What don't you like? How has your quality of life in Sitka changed over the past ten years? Do you think it will 
change for the better or worst (or stay the same) in the next ten years? For some interviews, all questions were asked, while in others only a limited selection were asked by the interviewer because the conversation allowed responses to be elicited in a more unstructured way (Patton, 2002)

Theoretical sampling was used to identify key-informants for interviews (Corbin \& Strauss, 2015). The theoretical interest and the interview questions guided the selection of members from the community best suited to study collaborative planning in a tourism context. A list of leaders in identified stakeholder groups (e.g., municipal government, tourism industry, public lands, recreation non-profit associations, environmental non-profit associations, harbor master and others working with cruise companies, tribal, media) was enumerated prior to data collection. During field interviews, researchers listened for additional community members who might assist in understanding the processes and outcomes of collaborative tourism planning. Interviewees were also asked to recommend further individuals who played a role or may have been omitted from the collaborative tourism planning exercise. Community members who were absent from the planning processes were also purposefully sought out and interviewed.

Several trips to the research site were made before the researchers agreed that the theoretical interest was fully explored. Over the trips, the sampling evolved such that interviews were conducted with individuals who were involved in many sectors including government, the tourism industry, other industries including commercial and charter fishing, and citizens who volunteered or were paid for management of tourism planning efforts (Table 1). Besides the two trips to Sitka in 2010 and 2011, several additional interviews were completed via telephone with individuals who contributed a new perspective. Additionally, several community meetings were observed during the two trips to Sitka, which helped researchers further understand the motives for tourism planning and the factors that influenced residents' views on tourism development and 
well-being. Trips to the community and interviews were ended when the researchers found data saturation (or the absence of new evidence) and no new variations on open coding themes were present in the data (Corbin \& Strauss, 2015). In total, 27 interviews were completed with key informants from the local and federal government, small business sector, non-profit sector, and community volunteers (Table 1).

Table 1. Key Informant Interview Summary

\begin{tabular}{lc}
\hline Role Category & Total Interviews \\
\hline Local Government Staff & 4 \\
Local Elected Official & 6 \\
Federal Government Staff & 4 \\
Small Business Owner or & 6 \\
Manager & 5 \\
Non-Profit Sector Leader & 2 \\
Volunteer & 27 \\
Total & \\
\hline Note: Interviews were attempted but not conducted with tribal leaders.
\end{tabular}

Note: Interviews were attempted but not conducted with tribal leaders.

The research team was comprised of five researchers to ensure two researchers were at each interview and all identified community members could be reached. All researchers were trained and experienced in interviewing methods and qualitative data analysis. Interviews were 30 to 60 minutes in length. Some interviews were taped with permission and later transcribed, while data from other interviews was limited to researcher notes. To ensure validity of researcher notes the two or more researchers present during an interview individually typed their field notes and then discussed and integrated the data while in the field. This was often done hours after interviews or by the end of the day. On the first trip to the community when all five researchers were present and a majority of the interviews occurred, a focus group of the researchers was conducted to begin the open coding or theme generating process. Emergent themes from the interview data were inventoried, documented, and discussed. Three of the initial researchers 
returned to the research site to conduct additional interviews to achieve theoretical interest completion. Following Xiao and Smith's (2006) case study tactics to test for validity, construct validity was achieved by sharing data memos with a few key informants to validate themes and chains of evidence across participants and interviews to the plan document. Internal validity was achieved with the use of multiple researchers present and note taking at each interview as well as discussions and a focus group style session for explanation building while in the field. External validity was achieved with the use of Jamal and Getz's (1995) collaborative tourism planning propositions. Reliability was achieved using an interview script and databases with extensive interview field notes.

With interview generated data, the researchers applied Corbin and Strauss's (2015) "interplay between structure and process" framework to analyze data for themes and subthemes with a focus on the process of collaborative planning and the underlying structure of motives for participating and the intended consequences of the planning process. A combination of themes, subthemes or factors, and quotes were used to address the theoretical interest of collaborative planning and subjective well-being. Some quotes were directly from interviews and others were compiled from researcher notes using a best effort to get exact wording correct. Other quotes are directly from the planning document as a proxy of residents' perspectives.

\section{Findings and Discussion}

Findings are organized around four primary areas of inquiry to address the theme of the special issue on the tourism development and subjective well-being in small island contexts, and to contribute to knowledge and testing of collaborative planning theory (Jamal \& Getz, 1995). First, subjective well-being as defined by the participants is presented. Second, factors that were found to influence the meaning and perception of subjective well-being in a small island tourism destination are described. Third, results regarding community concerns regarding tourism 
impacting well-being which served as a primary impetus for tourism planning are summarized. Finally, the process of collaborative tourism planning for providing further opportunity to deliberate about subjective well-being at a local level is discussed.

\section{Defining Subjective Well-Being}

The consideration of subjective well-being at an individual and community level was a key premise at the onset of Sitka's entry into serious discussions about tourism development. The structure and content of the collaborative tourism planning process provided evidence of how Sitka residents defined well-being in their community. The tourism plan was initiated by a volunteer long-range planning committee that received funding from the local government to pay for a planning effort with a tourism plan as a final deliverable. The tourism plan was completed after a year-long process of over 30 community meetings that were led by local facilitators. The planning process was open to all interested stakeholders. Participating community members followed established collaborative planning principles outlined by Chrislip and Larson (1994). Other communities in Alaska had recently adopted Chrislip and Larson's approach and those Sitka residents who were initially interested in a community discussion about tourism felt many of the collaborative tenets matched their desired process. The goal of the planning group was to create "a sustainable plan that maximizes the contributions and minimizes the impacts of the visitor industry so that a good quality of life for residents is realized" (Turner \& Boettcher, 2007, Overview Page). They aimed to protect the community's unique qualities and sense of community as internal and external factors placed development pressure on the community. Planning principles detailed in the planning document demonstrate a focus on well-being, including the town hosting locally-owned and operated businesses, the visitor industry maximizing benefits to the residents (over outsiders), developing partnerships that are important 
for implementation and unified community decision making, and encouraging an open dialogue regarding tourism's community impacts based on sound information.

Factors Influencing Subjective Well-being

The first characteristic that influenced residents' views about well-being was their length of residency and the economic cycles they experienced as an island inhabitant. Those who were second or third generation residents or had lived in Sitka more than 20 years recalled the economic cycles, related mostly to natural resources, which impacted their overall well-being. A long-time resident shared:

Community and economic development planning was pushed to the forefront after the pulp mill closed in 1993. There was a sense that the community would experience economic losses and that planning, or at least thinking about the future, was the way to improve conditions (well-being). Tourism planning, in particular, was prompted by the closing of the pulp mill. Community planning occurred AFTER the community was threatened by the loss of a large employer. That is, the community was responding to a community shock or negative experience through evaluating current circumstances and thinking about future priorities.

Source of livelihood, and associated industry sector position within the community, were frequently mentioned as characteristics that significantly impacted the perception of well-being. Highlighting the relationship, a long-time resident who owned a charter fishing business shared views about well-being and how the role of tourism varies by employment sector:

20 years ago there was not as much tourism, the mill and commercial fishing were the leading industries. Through the years, tourism grew and became almost circus-like. And, then Sitkans started to fear becoming like Juneau or Ketchikan. 
Sitka, in particular, is filled with opinionated people and is extremely cliquish. There are also extreme environmentalists in Sitka....The finished tourism plan document dealt with all community segments. It dealt with tourism, while also protecting the quality of life. The planning group "thought of everything" and also built in "loopholes" so future decision makers had a way out of decisions, or a way out of mistakes, or a way to protect life.

A final prominent factor that emerged during interviews was the importance of the role(s) the individual held in the community. Roles varied including small business owners, elected officials, federal and local government employees, members and staff of non-profit organizations, and community volunteers. In a small island community, many people held multiple roles as paid employee, elected official or volunteer across a variety of community organizations and industries. Two interview excerpts, in particular, highlight the range of perspectives on how community role influences opinion regarding actions needed to protect well-being. The first quote is from a long-time resident who was a volunteer during the planning processes (paraphrased from researcher notes):

Before the tourism planning started, she started to notice that there was more talk around town about tourism getting out of control... Someone from the community wrote an articulate letter to the editor talking about tourism growth and quality of life. There was concern that tourism had reached a certain point and locals would stop shopping at downtown stores. She started getting concerned and began meeting with other folks who were not necessarily folks she would have otherwise talked to around town. Rumors were spreading about risks to quality of life from tourism saturation, fear of becoming like other overcrowded Alaska cruise port destinations. A group of concerned citizens decided someone should get involved 
with the long-term planning commission. A group brought Chrislip to town and decided to use tourism as a model for community collaboration. They brainstormed about additional folks to help think about tourism in the community and invited additional participants.

Another quote from a newer resident who participated in planning as a federal employee (paraphrased from researcher notes):

She noted the following as the largest challenges to planning in Sitka: 1) seasonality of work and residents; 2) difficulty finding time to work on planning efforts (volunteer time); 3) challenges in determining the unheard majority... "when you sing to the choir, you hear the same voices"; 4) challenges in including the Alaska Native voice; and 5) a divided community - those who participate and those who don't and different interest groups that are polarized. She identified money, time, and leadership as challenges to plan implementation. She noted local citizens generally try to be active and conduct activities for the betterment of the community, but it is very difficult without money and time. One of the biggest challenges in Sitka is that everyone is already busy volunteering for other causes. It is hard to get people together because you end up putting one thing on the wayside to deal with another.

Subjective Well-Being and Tourism Planning

Qualitative analysis revealed that the tourism planning process was focused on subjective well-being. Many members of the community were keen on creating a new form of tourism marketing and management that would ensure maximum social and economic gains for many residents, not just select residents or outside interests. It is likely the planning process would not have occurred if residents had been satisfied with the current tourism industry, community 
impacts, and overall well-being. Inquiries that were originally framed by the researchers as quality of life were discussed as well-being by community members. Those individuals interviewed, participants and nonparticipants to the planning process, saw the collaborative process as an attempt to determine the appropriate mix of local and nonlocal tourism development. Additionally, the process was deliberately intended to develop a strategy to respond to industry volatility from international to local economic influences. Less intentional in the process was a rising local movement to guide local tourism development and other locally sourced resources and staffing. While the community currently had both locally-owned and operated tourism businesses and nonlocal or international cruise tourism, the planning effort was directed toward the mix of local and nonlocal, control over decision making, and power structures that might trump local wishes (see Jordan et al., 2013).

The collaboratively created plan includes an analysis of tourism segments (e.g., independent travelers, cruise tourists, meeting and conference visitors) including historical data on arrivals to the island. Trends data in highlight volatile annual tourist arrivals during the prior 15-year period, primarily because cruise ship arrivals changed each year. The reasons offered included the health of the economy, size of cruise ships, cruise firms selecting some ports over others, and the absence of a large-scale dock for hosting large cruise ships. Additional local challenges heard during the interviews were the cost and complexity of traveling to Sitka, limited availability of accommodations during peak summer season, some gaps in attractions, and community disagreement regarding visitor industry goals and priorities.

The greatest concern (most frequently mentioned during interviews) focused on sustaining locally-owned businesses. Local was viewed as an important economic asset. Local versus nonlocal was a way of retaining jobs for those with long histories on the small island over jobs and profits to short-term residents or large tourism companies with no personal investments 
in the community. A related concern was any tourism development (i.e., infrastructure, downtown businesses, transportation services, recreation activities) needed to be desirable, useful, and available to local residents throughout the year, not just during tourism seasons. The community was also concerned about local control of tourism decision making and marketing. Several individuals interviewed expressed that the city, convention and visitors bureau, and businesses should control promoting its attractions and not depend on outside marketing efforts.

\section{Collaborative Tourism Planning Addresses Subjective Well-Being Concerns}

The impetus for the tourism plan was to ensure the community had control over the tourism industry and their own well-being. The collaborative planning process resulted in a document outlining a visitor industry oversight committee that was promoted as the main tool to maintain checks and balances over uncontrolled tourism developments or outside influences on local tourism. The intent of this oversight was that "visitor industry entities, government leaders, and residents can work together in continuous oversight of the Visitor Industry Plan" (Turner \& Boettcher, 2007, p. 1 in VI Plan Oversight Section). One way this planning group viewed the implementation of oversight was to establish a new committee under local government (not just relying on the established convention and visitors bureau that primarily marketed the destination) as a way to align tourism planning with comprehensive local government land use and services planning. These steps were documented in the plan and were believed to allow for two-way communication about tourism activities and impacts, to fund better research on tourism impacts, and to control visitation to avoid seasonal peaks and allow for resting periods. An example of setting a standard for tourist levels was "Ideally, the cruise schedulers should respect Sitka's request that cruise ships call on low traffic days rather than adding a third or fourth ship on a day. Also, weekends should be relatively quiet (from cruise ships) giving the community a chance to rest during the busy season” (Turner \& Boettcher, 2007, p. 1 in VI Plan Oversight Section). 
The plan featured incentives and policies aimed at "creating strategies to maintain and enhance the qualities that make Sitka a special place to live and visit" (Turner \& Boettcher, 2007, p. 1 in Incentives and Policies). These policies would be used to monitor predetermined standards for community economics, downtown character, and the environment. Examples of programs to support these policies included incentives for environmentally-friendly transportation, for business owners to pay living employee wages, and for starting new local businesses. The plan also provided guidelines for divisive situations where community voices could be heard and fully considered regarding more than economic return from tourism development. Specifically, the plan included a recommendation that any action taken by the locally-elected body would allow for meaningful community dialogue prior to making major decisions regarding tourism development. The intent of this stipulation was not to dead-end ideas, but rather to resolve conflict and fully explore contentious issues impacting well-being for the sake of innovative problem solving and greater community cohesion. The plan further suggested "It is important for the outreach committee to build community trust in this type of process and show how the benefits of resolving difficult issues through community dialogue outweigh the risks of being involved. Inclusive dialogue promotes broad understanding of complex issues; and innovative, proactive, and unexpected solutions" (Turner \& Boettcher, 2007, p. 1 in Outreach Section).

\section{Conclusions}

The qualitative analysis of over two dozen interviews provides evidence of how small island community address community well being through collaborative tourism planning. The researchers were particularly interested in the success and challenge associated with a collaborative tourism planning process to examine some of Jamal and Getz's (1995) propositions in a small island context. Their proposition (4) regarding full participation from stakeholders was 
an aim of Sitka's collaborative planning group, however the inability to gain and sustain full participation impeded the achievement of another proposition (3), that recommendations in a plan would be implemented. The case study on Sitka's collaborative planning demonstrates the interplay across elements of a tourism planning effort that was more grounded in local residents, than it was administratively mandated by government.

Alaska, like other states or countries with large water bodies that facilitate cruise tourism, views the cruise industry as an opportunity for economic growth. However, there is also growing concern by local communities about the costs of attracting and accommodating small and large vessels. Island communities like Sitka have found themselves offering attractive experiences for cruise visitors while their small town infrastructure is inadequate to dock and service larger ships with greater volumes of visitors. At the time of this research, Sitka was a community with high levels of community debate and engagement compared to other nearby communities, thus making it a rich case study to closely examine residents' perspectives on well-being and the process and outcomes of collaborative tourism planning.

Study findings highlight residents' concerns about well-being. Residents were found to be acutely aware of their well-being. Most people enjoyed living in the community, were employed, and tourism demand and supply had grown in recent years. The impetus for the tourism plan was a perceived threat to well-being and the local operation of tourism businesses that was being attributed to misguided, mismanaged, poorly conceived, or nonlocal tourism development. The long-range tourism planning effort was believed to be the vehicle for community consideration of a tourism industry that was deemed widely acceptable by local residents and could be locally marketed and managed. Many of the views and actions related to tourism planning efforts were closely linked to retaining the ability to self-determine quality of life (Ryan \& Deci, 2000). This case study found that residents who participated in tourism 
planning tended to be active, thoughtful, curious, inspired, and desired to contribute their talents to the community. Moreover, using a collaborative approach to planning reflected their desire to be integrated and inclusive of all those who wanted to participate. Their efforts were focused on protecting future well-being without extinguishing tourism development or tourist arrivals to the island.

After a year of work on the locally driven tourism plan that was presented to Sitka's governing body, the plan was not endorsed or supported by the local government or the industryled convention and visitors bureau. The lack of support was attributed to a failure to garner representative and full participation in the process. The researchers attributed this outcome to inconsistent motives for participation. Participation by local government officials was motivated by governance, the tourism industry was motivated by economics, and residents had a therapeutic motivation. Local governments are often required to conduct or fund planning initiatives to provide oversight and accountability for public funds collected via taxation. The tourism industry, comprised of accommodations, attractions, transportation, and food services generally desires a greater volume of tourists (or greater spending) to create higher economic benefits. Both government and tourism industry are driven by extrinsic motives. Residents who continued to be involved in tourism planning possessed self-directed initiative that could be considered therapeutic. The destination management implication of this finding is to regularly solicit and include resident input on tourism investments and programs. This could come in the form of public-at-large seat on a destination board, closer ties between business associations such as chambers of commerce or downtown associations, or more regular dialogue between residents and tourism officials.

A collaborative planning process was a rare chance for residents to be involved in tourism planning and leadership in a community. The planning process was an attempt at a more 
holistic approach to tourism planning and implementation in their community with some resident control over tourism marketing. In most domestic destinations, a convention and visitors bureau may not have much involvement in community planning but instead has been charged (and motivated) to "get heads in beds" and increase bed taxes, which they mostly receive back in their marketing budgets. For some members of the collaborative planning process who were not employed in tourism businesses, this was an opportunity to have a voice in tourism marketing and management strategies.

The collaborative approach was better suited for the "therapeutic" motives that some local residents held alongside the industry and government motives held by other participants. The plan emphasized maintaining a high quality of life for residents yet stressed a need for success in an increasingly competitive marketplace. The collaborative process reinforced the need for listening to residents about how they view their own subjective well-being and how tourism can enhance or detract from well-being. The cruise industry generally needs larger and more permanent infrastructure to operate, with some costs borne by local residents. The collaborative process highlighted the need for diversified tourist segments, including cruise and independent visitors. Many saw the needs of these sectors as being different and thus the community needed to invest in tourism systems that accommodated both. The intense focus on planning in Sitka also highlighted a need for more regular scheduled and open forums to consider new ideas to improve the economy, environment, quality of life, and well-being. Finally, as a small island there is growing support to develop businesses and other jobs that use local resources in order to minimize the need to import goods and services. Reducing importation increases the affordability of locally-sourced goods and reduces supply chain environmental impacts (Beamon, 1999).

Many studies proclaim the benefits of planning and far more studies are predicated on the 
logic that conducting planning will lead to a better, improved, more successful tourism industry, but relatively few studies have empirically demonstrated these outcomes. This study adds to knowledge about tourism planning, particularly collaborative processes that aim to give all residents and stakeholders an opportunity to be involved in the creation of tourism services, experiences, and infrastructure. This research demonstrates the complex relationship of subjective well-being and collaborative tourism planning implemented in a small island tourism destination.

Limitations of this research are that case studies are not generalizable to other places. The perspectives of all residents or stakeholder groups in the community studied were not included, therefore certain perspectives such as those of tribal members are not represented. The transportation sector that brings tourists to the island was also not included, primarily on the basis that they are servicing the island and are not residents of the island.

Future research should continue to monitor Sitka or similar communities on well-being and tourism planning and implementation. Lessons learned in the planning process might emerge during the next plan cycle. Additionally, future research could examine more directly how specific tourism development decisions alter subjective well-being. Another area of inquiry that few have studied (e.g., Caton \& Santos, 2009; Santos, 2004) is how resident quality of life is featured in community-controlled promotional communications to attract tourists rather than new residents or businesses. These types of studies will further contextualize how local, embedded experiences are intended to achieve a desired balance of economic livelihoods for residents, social engagement for locals and tourists, and sustaining the land and water natural resource for future generations. 


\section{References}

Andereck, K. L., Valentine, K. M., Knopf, R. C., \& Vogt, C. A. (2005). Residents' perceptions of community tourism impacts. Annals of Tourism Research, 32(4), 1056-1076. http://doi.org/10.1016/j.annals.2005.03.001

Beamon, B. M. (1999). Designing the green supply chain. Logistics Information Management, 12(4), 332-342. http://doi.org/10.1108/09576059910284159

Bramwell, B., \& Sharman, A. (1999). Collaboration in local tourism policymaking. Annals of Tourism Research, 26(2), 392-415. http://doi.org/10.1016/s0160-7383(98)00105-4

Byrd, E. T. (2007). Stakeholders in sustainable tourism development and their roles: Applying stakeholder theory to sustainable tourism development. Tourism Review, 62(2), 6-13. http://doi.org/10.1108/16605370780000309

Carlsen, J., \& Butler, R. (Eds.). (2011). Island tourism: Sustainable perspectives. Wallingford: CABI. Retrieved from http://www.cabi.org/cabebooks/ebook/20113094519

Caton, K., \& Santos, C. A. (2009). Images of the other selling study abroad in a postcolonial world. Journal of Travel Research, 48(2), 191-204. http://doi.org/10.1177/0047287509332309

Chrislip, D. D., \& Larson, C. E. (1994). Collaborative Leadership: How Citizens and Civic Leaders Can Make a Difference. San Francisco, CA: Jossey-Brass.

Corbin, J. M., \& Strauss, A. L. (2015). Basics of qualitative research: Techniques and procedures for developing grounded theory (Fourth edition). Los Angeles: SAGE.

Costanza, R., Fisher, B., Ali, S., Beer, C., Bond, L., Boumans, R., ... Snapp, R. (2007). Quality of life: An approach integrating opportunities, human needs, and subjective well-being. Ecological Economics, 61(2-3), 267-276. http://doi.org/10.1016/j.ecolecon.2006.02.023 
Cross, M., \& Nutley, S. (1999). Insularity and accessibility: The small island communities of western Ireland. Journal of Rural Studies, 15(3), 317-330. http://doi.org/10.1016/S07430167(98)00062-X

Crotty, M. (1998). The foundations of social research: Meaning and perspective in the research process. Thousand Oaks, CA: SAGE.

Cruise Line Agencies of Alaska. (2012). Yearly Passenger (PAX) Counts. CLAA.

DeNeve, K. M., \& Cooper, H. (1998). The happy personality: A meta-analysis of 137 personality traits and subjective well-being. Psychological Bulletin, 124(2), 197-229. http://doi.org/10.1037/0033-2909.124.2.197

Diener, E. (2000). Subjective well-being: The science of happiness and a proposal for a national index. American Psychologist, 55(1), 34-43. http://doi.org/10.1037/0003-066X.55.1.34

Diener, E., \& Chan, M. Y. (2011). Happy people live longer: Subjective well-being contributes to health and longevity. Applied Psychology: Health and Well-Being, 3(1), 1-43. http://doi.org/10.1111/j.1758-0854.2010.01045.x

Diener, E., Lucas, R. E., \& Oishi, S. (2009). Subjective well-being. In E. Diener (Ed.), The Science of Well-Being (pp. 11-58). Springer. Retrieved from http://link.springer.com/chapter/10.1007/978-90-481-2350-6_2

Diener, E., Suh, E. M., Lucas, R. E., \& Smith, H. L. (1999). Subjective well-being: Three decades of progress. Psychological Bulletin, 125(2), 276-302. http://doi.org/10.1037/0033-2909.125.2.276

Dolan, P., Peasgood, T., \& White, M. (2008). Do we really know what makes us happy? A review of the economic literature on the factors associated with subjective well-being. Journal of Economic Psychology, 29(1), 94-122. http://doi.org/10.1016/j.joep.2007.09.001 
Douglas, C. H. (2006). Small island states and territories: Sustainable development issues and strategies - challenges for changing islands in a changing world. Sustainable Development, 14(2), 75-80. http://doi.org/10.1002/sd.297

Gilbertson, N. (2003). Sitka: An economic profile. Alaska Economic Trends, 23(2), 3-11.

Go, F. M., Milne, D., \& Whittles, L. J. R. (1992). Communities as destinations: A marketing taxonomy for the effective implementation of the tourism action plan. Journal of Travel Research, 30(4), 31-37. http://doi.org/10.1177/004728759203000405

Green, R. (2005). Community perceptions of environmental and social change and tourism development on the island of Koh Samui, Thailand. Journal of Environmental Psychology, 25(1), 37-56. http://doi.org/10.1016/j.jenvp.2004.09.007

Gunn, C. A. (1988). Tourism planning. New York: Taylor and Francis.

Hamzah, A., \& Hampton, M. P. (2013). Resilience and non-linear change in island tourism. Tourism Geographies, 15(1), 43-67. http://doi.org/10.1080/14616688.2012.675582

Jamal, T. B., \& Getz, D. (1995). Collaboration theory and community tourism planning. Annals of Tourism Research, 22(1), 186-204. http://doi.org/10.1016/0160-7383(94)00067-3

Jamal, T. B., \& Stronza, A. (2009). Collaboration theory and tourism practice in protected areas: Stakeholders, structuring and sustainability. Journal of Sustainable Tourism, 17(2), 169189. http://doi.org/10.1080/09669580802495741

Jordan, E. J. (2015). Planning as a coping response to proposed tourism development. Journal of Travel Research, 54(3). http://doi.org/10.1177/0047287513517425

Jordan, E. J., Vogt, C. A., Kruger, L. E., \& Grewe, N. (2013). The interplay of governance, power and citizen participation in community tourism planning. Journal of Policy Research in Tourism, Leisure and Events, 5(3), 270-288.

http://doi.org/10.1080/19407963.2013.789354 
Kahneman, D., \& Krueger, A. B. (2006). Developments in the measurement of subjective wellbeing. The Journal of Economic Perspectives, 20(1), 3-24. http://doi.org/10.1257/089533006776526030

Lim, C. C., \& Cooper, C. (2009). Beyond sustainability: Optimising island tourism development. International Journal of Tourism Research, 11(1), 89-103. http://doi.org/10.1002/jtr.688

Luhmann, M., Hofmann, W., Eid, M., \& Lucas, R. E. (2012). Subjective well-being and adaptation to life events: A meta-analysis. Journal of Personality and Social Psychology, 102(3), 592-615. http://doi.org/10.1037/a0025948

Madrigal, R. (1995). Residents' perceptions and the role of government. Annals of Tourism Research, 22(1), 86-102. http://doi.org/10.1016/0160-7383(94)00070-9

Moscardo, G. (2011). Exploring social representations of tourism planning: issues for governance. Journal of Sustainable Tourism, 19(4-5), 423-436. http://doi.org/10.1080/09669582.2011.558625

Nunkoo, R., \& Ramkissoon, H. (2010). Small island urban tourism: a residents' perspective. Current Issues in Tourism, 13(1), 37-60. http://doi.org/10.1080/13683500802499414

Nunkoo, R., \& Ramkissoon, H. (2011). Developing a community support model for tourism. Annals of Tourism Research, 38(3), 964-988. http://doi.org/10.1016/j.annals.2011.01.017

Okazaki, E. (2008). A Community-based tourism model: Its conception and use. Journal of Sustainable Tourism, 16(5), 511-529. http://doi.org/10.1080/09669580802159594

Patton, M. Q. (2002). Qualitative Research and Evaluation Methods (3rd ed.). Thousand Oaks, CA: SAGE.

Pearce, D. G. (1989). Tourist development (2nd ed). Harlow, Essex, England : New York: Longman Scientific \& Technical ; Wiley. 
Plummer, R., Kulczycki, C., \& Stacey, C. (2006). How are we working together? A framework to assess collaborative arrangements in nature-based tourism. Current Issues in Tourism, 9(6), 499-515. http://doi.org/10.2167/cit284.0

Ritchie, J. R. B. (1993). Crafting a destination vision: Putting the concept of resident responsive tourism into practice. Tourism Management, 14(5), 379-389. http://doi.org/10.1016/0261-5177(93)90006-7

Ryan, R. M., \& Deci, E. L. (2000). Self-determination theory and the facilitation of intrinsic motivation, social development, and well-being. American Psychologist, 55(1), 68-78. http://doi.org/10.1037/0003-066X.55.1.68

Santos, C. A. (2004). Framing Portugal: Representational dynamics. Annals of Tourism Research, 31(1), 122-138. http://doi.org/10.1016/j.annals.2003.08.005

Schalock, R. L. (1997). Quality of life: Application to persons with disabilities. AAMR.

Scheyvens, R., \& Momsen, J. (2008a). Tourism in small island states: From vulnerability to strengths. Journal of Sustainable Tourism, 16(5), 491-510. http://doi.org/10.1080/09669580802159586

Scheyvens, R., \& Momsen, J. H. (2008b). Tourism and poverty reduction: Issues for small island states. Tourism Geographies, 10(1), 22-41. http://doi.org/10.1080/14616680701825115

Seetanah, B. (2011). Assessing the dynamic economic impact of tourism for island economies. Annals of Tourism Research, 38(1), 291-308. http://doi.org/10.1016/j.annals.2010.08.009

Shareef, R., \& McAleer, M. (2005). Modelling international tourism demand and volatility in small island tourism economies. International Journal of Tourism Research, 7(6), 313333. http://doi.org/10.1002/jtr.538

Stake, R. E. (1978). The case study method in social inquiry. Educational Researcher, 7(2), 5-8. http://doi.org/10.2307/1174340 
Turner, M. T., \& Boettcher, K. (2007). Sitka Visitor Industry Plan (Version 1.0). City and Borough of Sitka, Alaska. Retrieved from http://www.cityofsitka.com/government/departments/publicworks/documents/SitkaVistor Planversion1.0.pdf

Wood, D. J., \& Gray, B. (1991). Toward a comprehensive theory of collaboration. The Journal of Applied Behavioral Science, 27(2), 139-162. http://doi.org/10.1177/0021886391272001

Xiao, H., \& Smith, S. L. J. (2006). The making of tourism research: Insights from a Social Sciences Journal. Annals of Tourism Research, 33(2), 490-507. http://doi.org/10.1016/j.annals.2006.01.004

Yin, R. K. (2012). Applications of case study research (3rd ed). Thousand Oaks, Calif: SAGE. Yuksel, F., Bramwell, B., \& Yuksel, A. (1999). Stakeholder interviews and tourism planning at Pamukkale, Turkey. Tourism Management, 20(3), 351-360. http://doi.org/10.1016/S0261-5177(98)00117-4

Zapata, M. J., \& Hall, C. M. (2012). Public-private collaboration in the tourism sector: balancing legitimacy and effectiveness in local tourism partnerships. The Spanish case. Journal of Policy Research in Tourism, Leisure and Events, 4(1), 61-83.

http://doi.org/10.1080/19407963.2011.634069 